\title{
Internalization of Moslem Characteristic in Elementary School: A Self-determination Theory Perspective
}

\author{
Lilis Kurniawati ${ }^{1 *}$ \& Muhammad Rafdi Al Huda \\ $1^{*}$ Universitas Muhammadiyah Surakarta, Surakarta, Indonesia \\ ${ }^{2}$ Al Azhar University, Cairo, Egypt \\ *Email \& Phone: a510160178@ums.ac.id; +6281235535739
}

\begin{tabular}{l} 
Submitted: 2021-09-12 \\
Accepted: 2021-10-16 \\
Published: 2021-12-20 https://doi.org/10.53088/eej.v1i1.147 \\
\hline Keywords:
\end{tabular}

\section{INTRODUCTION}

Brawls, rude speech, fights between students, bullying, smoking, narcotics abuse, cheating, lack of discipline, lack of responsibility (picket assignments and school assignments), and lack of student manners towards older people (principals, teachers, school guards). And canteen mothers) is a little illustration of educational problems in the elementary school environment (Rudyanto \& Retnoningtyas, 2018). 
Moral degradation occurs due to the swift currents of globalization and the rapid development of the times with extraordinary technological advances without adult supervision; this is exacerbated by the lack of instilling religious and character education in students in the family, school, and community environment (Wati \& Arif, 2017).

The problems that occur indicate a failure in educational institutions tasked with forming Indonesian people with character and noble character. This is because learning in schools related to religious and moral knowledge is only charged to religious teachers. In addition, the materials presented by the teacher in learning only focus on the cognitive aspects, while the affective and psychomotor aspects are minimal. The conditions and facts of moral degradation confirm that all teachers who teach any subject must understand the importance of inculcating character and try to implement it in the learning process (Arfin, 2017).

One of the values in character education is religious value. This value is eternal, absolute, and comes from trust in humans. The importance of this value was also stated by Wati $\&$ Arif (2017), who argue that efforts to solve the problem of moral degradation in students can be made by increasing the quality of faith and piety. In other words, the cultivation of religious values must be prioritized and followed by other aspects. Thus, it is expected that students can behave with good and bad measures based on religious provisions. This needs to be done continuously in the family, school, and community environment. Instilling religious values in the school environment can be done by integrating religious values in the learning process at school. Value integration needs to be done in all subjects, including science and social sciences (Aulia, 2014).

The author analyzed several similar studies on value integration to determine the quality of study and emphasize the importance of the topics discussed. First, Ariantini (2014) examines the implementation of integrating spiritual and social attitudes in Indonesian language learning based on the 2013 curriculum in seventh grade of Public Middle School 1 Singaraja. Second, Wati \& Arif (2017) examines the religious values instilled in Muhammadiyah Sidoarum Elementary School. Third, Aulia (2014) examines the three stages of character education in the Yogyakarta Juara Elementary School. Fourth, Mujizatullah (2018) examines the integration of religious character values in Indonesian subjects at Public High School 2 Majene, West Sulawesi. Fifth, Kurniawan (2013) examine the appropriate character values integrated into Civics subjects in elementary school. Sixth, Harahap (2016) examines the integration of Islamic religious values in the learning process at Public High School 1 Sihapas. Seventh, Islami (2016) examines character education in the learning process of English subjects at Public Islamic High School 1 Samarinda. Eighth, Suyitno (2019) examines the integration of character values in mathematics in Japan. Ninth, Muttaqin (2018) examines the strengthening of character values in elementary schools. Tenth, Marini (2018) examines the implementation of character education in Indonesia.

Based on the explanation, it can be concluded that the integration of religion values in Elementary schools in Indonesia is still very needed to be studied. There are only a few studies about integrating values, especially religion values. Based on the background, this study's objective is to (1) Reveal the values of religious characters integrated into the learning process at Elementary School. (2) Reveal teacher strategies in integrating religious values in the learning process at Elementary School.

\section{METHOD}

\section{Type and Design}

This type of study is qualitative with a case study approach. This study will describe the integrated religious values in the learning process, the teacher's strategy in integrating 
religious values in the learning process, and the driving and inhibiting factors in integrating religious values in the learning process at MI Muhammadiyah Bloran Elementary School (MI Muhammadiyah Bloran), Indonesia.

\section{Data and Data Sources}

The data in this study used qualitative data. The data collected in this study were from interview transcript data and documentation data. Sources of data in this study are informants consisting of four teachers, each from classes III, IV, V, and VI, with the condition that they have taught the class in question for at least one year. In addition, four students have strong memories, pay attention to teachers, and are communicative from class III, IV, $\mathrm{V}$, and VI MI Muhammadiyah Bloran, respectively.

In this study, the authors applied the ethical principles: (1) Obtained informed consent to all informants. (2) Protected informant's confidentiality. (3) Did not apply deceitful practices. (4) Gave informants the right to withdraw from the study.

Table 1. Description of Informants

\begin{tabular}{llllll}
\hline No & Initials & Role & Gender & $\begin{array}{l}\text { Teaching } \\
\text { Experience (Year) }\end{array}$ & $\begin{array}{l}\text { Age } \\
\text { (Year) }\end{array}$ \\
\hline 1 & IE & Class III A Teacher & Female & 6 & 30 \\
2 & BS & Class IV C Teacher & Male & 1 & 44 \\
3 & HE & Class V B Teacher & Female & 1 & 24 \\
4 & IN & Class VI B Teacher & Female & 10 & 42 \\
5 & SH & Class III A Student & Male & - & 9 \\
6 & BIL & Class IV C Student & Male & - & 10 \\
7 & ANN & Class V B Student & Female & - & 11 \\
8 & RAI & Class VI B Student & Female & - & 12 \\
\hline
\end{tabular}

\section{Data collection technique}

\section{Interview}

Interviews in this study were conducted with the teacher and student informants as data sources. The author collected data through telephone calls and asked the teacher and students several questions. Questions posed to teachers include:

- What do you know about integrating religious values in the learning process?

- What religious values are believed and integrated into the learning process at MI Muhammadiyah Bloran?

- What is the teacher's strategy to integrate religious values in the learning process at MI Muhammadiyah Bloran?

Questions posed to students include:

- What are religious values?

- Do teachers teach religious values in the learning process?

- What religious values do teachers teach in the learning process?

\section{Documentation}

Documentation used in this study is the profile, vision, mission, and objectives of $\mathrm{MI}$ Muhammadiyah Bloran and lesson plans for class III thematic subjects, class IV in science subjects, class V in mathematics, and class VI in Indonesian subjects at MI Muhammadiyah Bloran. 


\section{Data Validity}

The validation technique or data validity is carried out by using source triangulation and technical triangulation. According to Moleong (2013), triangulation is a technique of checking data validity by utilizing something other than the data to check or compare the data.

Source triangulation means that authors use the same data collection techniques from different sources. At the same time, technical triangulation means obtaining data from the same source with different techniques (Sugiyono, 2015).

In this study, triangulation of sources was carried out by comparing the results of interviews between teachers and students regarding the implementation of the integration of religious values in the learning process in schools. At the same time, the triangulation of techniques in this study was carried out by comparing the data from teacher interviews with the documentation data obtained.

\section{Data analysis}

Based on the problem formulation and study objectives, the data analysis used is an interactive model developed by Miles \& Huberman (2007), which was carried out through several stages, including: (1) Data collection, at this stage, the author transferred the results of the interviews into written form (interview transcripts). (2) Data reduction is made by selecting and simplifying the raw data (interview transcripts) by underlining the essential data. Data reduction focused on the results of interviews and documentation. (3) Presentation of data, data that has been sorted is presented in the form of a brief description in a Microsoft Word table. (4) Drawing conclusions is the last step which includes giving the meaning of the simplified data and then noting regularities, logical explanation patterns, and methodological configurations that allow predictability. The study problem obtains the final authentic data.

\section{RESULT}

Integrated Religious Character Values in the Learning Process

The program for integrating religious values in the learning process is prepared by the head of the school and the deputy head of the Islamic field. Furthermore, its implementation is the responsibility of teachers, students, and all staff employees. In particular, the target for integrating religious values is students, but in general, the targets for integrating religious values are all stakeholders in MI Muhammadiyah, including teachers, staff, students' parents, and the surrounding community. The short-term goal of integrating religious values in the learning process is for students to be able to apply the religious lessons learned in school, while the long-term goal is to shape Islamic character in students so that later they can grow up to be intelligent, virtuous, faithful, and pious individuals to Allah.

The integration of religious values in the learning process through three stages: planning, implementation, and evaluation. The following is a description of each of these stages:

The implementation of religious values at MI Muhammadiyah Bloran is carried out through school culture and the learning process in the classroom. The implementation of religious values in school culture is the responsibility of all stakeholders in the school, while the integration of religious values in the implementation of the learning process in the classroom is entirely the teacher's responsibility. Teachers act as role models and facilitators to instill religious values during the learning process. The following are the religious values that the teacher integrates into the implementation of the learning process: 


\section{Clean Faith}

A clean faith will grow a solid bond to Allah SWT. The existence of a strong bond will keep away from all actions that deviate from His path and provisions. Students are accustomed to consistently carrying out their obligations as Muslims. Activities that are reflected in integrating these values in implementing the learning process are prayer together at the beginning and end of each lesson. As stated by IE, BS, IN, and RAI:

"Before starting learning, students are accustomed to praying Duha and praying." (IE)

"Praying and greetings at the introduction and closing." (BS)

"Inserting in the introduction, namely praying. At the end of the prayer, greetings." (IN)

"Pray before and after study." (RAI)

\section{True Worship}

Students are accustomed to obeying religious orders correctly and adequately according to the instructions of the Qur'an and sunnah. Activities that are reflected in integrating these values are muroja'ah (memorize) Al-Qur'an in the preliminary activities, the Duha prayer before starting the lesson, and the Zuhur prayer in congregation during recess. As stated by IE, BS, IN, and IYA:

"Before starting learning, students are accustomed to praying Duha in a congregation, muroja'ah together in class, and praying." (IE)

"Students are required to perform the Zuhur prayer in the congregation." (BS)

"Muroja'ah short letter at the beginning of learning." (IN)

"Muroja'ah Qur'an every morning." (SYA)

\section{Sturdy Morals}

Students are taught to have good morals by always being polite, courteous, tolerant, mutually respectful, and respecting others. Activities that illustrate the integration of this value in the learning process are the teacher teaching students always to say hello, respect the teacher, speak politely to friends and teachers, call friends' names as mas or madam, and respect differences of opinion with friends. As stated by IE, ANN:

"From the beginning, students have been taught to greet the teachers, speak politely to friends and teachers, respect the teacher. Students are accustomed to respecting their friends by calling their friends' names as mas/madam, and respecting each other's opinions." (IE) 
"Examples of religious values that I carry out are respect and courtesy to elders, courtesy to teachers, respect for friends, and not discriminating between friends." (ANN)

\section{Strong Body}

Students are accustomed to implementing a healthy lifestyle by consuming halal, clean, and nutritious food and drinks to have strong stamina to carry out worship to Allah. The application of this value is that the school provides snacks and lunch for students every day, distributed during recess. As stated by IN:

"Students are accustomed to maintaining a healthy lifestyle by not being allowed to carry pocket money, not allowed to eat snacks at school, have to eat snacks and lunch provided by the school catering, or lunches from home." (IN)

\section{Extensive knowledge}

Students are accustomed to always thinking logically and critically in-class learning activities. Activities that reflect the integration of this value are that during the learning process, students are allowed to ask questions if they feel they do not understand, and at the end of each lesson, the teacher and students will ask questions and make conclusions about the material that has been studied. As stated by IN:

"I allow students to ask questions, then in the closing activity, I invite students to ask questions and make conclusions." (IN)

\section{Struggle Against Lust}

Students are taught to control their passions and obey existing regulations. The activity that illustrates the integration of this value is that students are always biased, to be honest and not cheat while working on daily assessment evaluation questions, mid-semester assessments, and end-of-semester assessments. As stated by BS, IN, and SYA:

"Honesty, for example, working on questions honestly, not cheating or asking friends during exams." (BS)

"The test may not cheat friends and be supervised by the teacher." (SYA)

"Evaluation includes attitude assessment, daily assessment, PTS, and PAS." (IN)

\section{Good at Keeping Time}

Students are accustomed to using their time with positive and valuable activities. The activity that is reflected in this value is that at the end of the learning activity (closing), there is usually ten minutes used by students to carry out BTA, students who are still Iqra reading Iqra, those who have read the Qur'an, and those who have read the Qur'an. Already the Qur'an can listen to his friend who is still Iqra. As IN stated: 
"Before the prayer closes the lesson, the lqra reads Iqra, and the Qur'an reads the Qur'an for ten minutes." (IN)

\section{Organized}

Students are always taught to be responsible, disciplined, careful, and thorough in doing their assignments. The activity reflected in this value is in the evaluation activity; students must try to solve the questions given by the teacher with responsibility, thoroughness, and on time. As stated by RAI and ANN:

"The value taught by the teacher in evaluation activities is a responsibility, namely by solving questions on time. (RAI)

"In evaluation, you must be responsible for doing assignments, and be thorough in solving problems." (ANN)

\section{independent}

Students are taught to have knowledge and skills so that later they can live independently, especially financially. Activities that are reflected in the integration of these values in the learning process are every Friday, on the sidelines of learning activities, the teacher asks students to collect the trash that has been brought from home. As stated by IA and ANN:

\footnotetext{
"Alms is implemented by getting students to give alms to the garbage every Friday in between lessons." (HE)

"One of the religious values that I carry out in my daily life is trash alms." (ANN)
}

\section{Helpful for Others}

Students are always taught to be helpful human beings. The activity that reflects the integration of this value is that students are accustomed to helping friends by applying peer teaching, where students can teach friends who cannot. As stated by HE:

"Teachers always provide understanding of the importance of applying religious values in life, such as helping friends who do not understand the material and also inviting students to implement values during the learning process. " (HE)

\section{Teacher's Strategy in Integrating Religious Values in the Learning Process}

The strategy of integrating religious values in the learning process at MI Muhammadiyah Bloran is carried out by: 


\section{Assignment}

After the learning activities are completed, the teacher will evaluate by giving assignments to students. Giving assignments to students aims to determine the level of students' understanding of the material and foster responsibility. As stated by IA, IE, and ANN as follows:

"Evaluation is done by giving questions or questions to students to find out the extent of their understanding of the material presented." (HE)

"Teachers must evaluate at the end of each lesson to find out whether students understand the material we convey or not. Evaluation can be in the form of assignments, tests, or questions and answers. (IE)

"In evaluation activities, the teacher teaches responsibility for doing assignments." (ANN)

\section{Observing Students in Doing Assignments}

In implementing the evaluation process, the teacher will carry out strict supervision, such as when students work on daily assessment questions, mid-semester assessments, and end-of-semester assessments. Usually, the teacher will turn the table over during an exam so that the drawer is facing forward and remind students to be honest and serious in doing their work. As stated by BS, SYA, and BIL:

"The strategy for integrating religious values in the evaluation process is to turn the table over during exams, so that the drawers face forward, carry out strict supervision during exams, and remind students to be honest and earnest in doing assignments." (BS)

"You cannot cheat on the test, and the teacher supervises the test." (SYA \& BIL)

\section{Master's Example}

The teacher gives examples in the form of commendable actions and attitudes. Besides that, the teacher always invites and repeatedly reminds students to apply religious values in everyday life. For example, the teacher sets an example by saying good, neat, and friendly words. As stated by IE, IA, BIL, and ANN:

"I instill habits by setting a direct example to students through daily habits." (IE)

"Always repeatedly teaches, gives an understanding of the importance of religious values, provides examples, invites students to practice, and applies religious values in every learning and activity carried out at school." (HE) 
"Teachers set an example by always saying kind, neat, and friendly words." (BILL)

"Teachers provide examples or examples of activities." (BIL \& ANN)

\section{Translating the Vision and Mission of School with Islamic Values in the Learning Environment}

The vision and mission of MI Muhammadiyah Bloran is "Generation who is devoted, intelligent and has character of Karimah". The school tries to achieve the vision and mission by including religious values in the lesson plans, implementing the integration of religious values in the learning process, and evaluating learning. As stated by all teachers that:

"Yes, I integrate religious values in the process of planning, implementing, and evaluating learning." (IE, BS, IA, IN)

\section{Implementation of Learning Programs with Islamic Values}

The Islamic nuanced learning program is carried out by the teacher by carrying out (1) greetings and prayers at the beginning and end of learning, (2) muroja'ah in preliminary activities, (3) school catering, (4) garbage alms, (5) BTA, (6) peer teaching. and (7) the congregational Duha, Zuhur, and Friday prayers. As stated by BS, IA, and IN:

"Praying and greetings at the introduction and closing." (BS)

"Alms is implemented by getting students to give alms to garbage every Friday in between lessons and helping friends who do not understand the material." (HE)

"Starting learning with greetings, prayers, reciting; usually there is 10 minutes at the end of the lesson used for students who are Iqra to read Iqra, the Koran reads the Koran, sometimes those who have the Koran listen to those who are still Iqra; maintain a healthy lifestyle (no pocket money, no snacks at school, must eat catering or lunch from home); and the congregational Duha, Zuhur, and Friday prayers. The goal is for students to get used to performing congregational prayers at home." (IN)

\section{Giving Motivation}

The teacher gives appreciation and motivation to students who have tried to behave well so that this behavior can be maintained. Examples are motivating by telling stories, stories of the prophet, stories of the prophet's companions, and stories of personal experiences. They can take lessons from this story. In addition, usually after students pray the teacher says "Keep your prayer, because when you lose it you will lose the others." As stated by IN and IA: 
"Motivating by telling stories of the prophet/ story of the prophet's companions/ stories of my experiences. From that story they can take a lesson." (IN)

"If students have behaved well, they will continue to be appreciated and motivated so that the behavior can be maintained. For example, after the students prayed, I said, "Watch your prayer, because when you lose it you will lose the others." (HE)

\title{
Giving Advice
}

The teacher advises students who make mistakes and disobey rules such as chatting, joking, and falling asleep in class. The advice given is usually associated with religion. The purpose of giving advice is so that students will not repeat their mistakes in the future. As stated by IN and IA:

\author{
"Advise students at all times, whatever the incident is related to \\ religion." (IN) \\ "If students don't obey the rules such as chatting, joking, and \\ falling asleep in class, I will give advice so that it doesn't happen \\ again in the future." (HE)
}

\section{Sanctions}

The teacher gives strict sanctions to students who do less commendable actions such as being crowded in class, smoking, truancy, being late, fighting, and not doing their homework. Sanctions are given according to the level of violation committed, gradually starting from light to severe sanctions according to the level of error and are educational in nature which aims to discipline and shape the character of students. Examples of sanctions given by teachers are memorizing short letters, writing surahs, writing statements signed by teachers and parents, cleaning the bathroom, istigfar a thousand times in front of the class, and collecting garbage. As stated by IE, BS, IN, SYA, BIL, ANN, and RAI:

"Obviously, the sanctions, apart from being a deterrent, must also be educational. Usually by memorizing the surah, writing the surah, it can also be by copying Juz Amma if the mistake is made many times. I will give sanctions to students who violate the rules such as smoking, fighting, and skipping classes." (IE)

"Imposing sanctions according to the level of violations committed, gradually starting from light to severe sanctions according to the level of error. Example: istigfar 1000 times in front." (BS)

"Memorizing short letters, if you repeat them again, you have to memorize longer letters, make a statement that must be signed by teachers and parents, and clean the bathroom." (IN) 
"They will be penalized if they miss or fight. The sanction given by the teacher is usually reading a short letter by rote." (SYA)

"They are given sanctions if they are absent, do not do their homework and are late, the sanctions are to come to the front of the class to read istigfar and pick up trash." (BILL)

"If you are busy and don't pay attention to the teacher, you have to come forward and istigfar 1000 times." (AAN)

"Memorizing the Qur'an, cleaning the bathroom, and writing a statement not to repeat the violated act." (RAI)

\section{Gift-giving}

Teachers give prizes to students who behave well and apply religious values. The purpose of giving gifts is to keep them motivated to continue to behave well in everyday life. Prizes are usually given to students who succeed in answering the teacher's questions, get good test scores, and succeed in getting class winners. Prizes are usually grades, money, stars, praise, and stationery such as pencils, pens, and erasers. As stated by IE, IN, SYA, BIL, ANN, RAI:

"Usually we give rewards to exemplary students in our school. Each class usually gives different rewards, for my class I usually give stars, then if students have collected 10 stars they can be exchanged for prizes." (IE)

"Usually I give you a pencil and an eraser. My goal is to motivate them to behave well." (IN)

"If someone answers the teacher's questions correctly, they get good test scores and they win the class. The gift from the teacher is to be given grades and stars." (SYA)

"In the past I managed to answer the teacher's questions then I got a prize money, then I put it in a piggy bank." (BILL)

"There are gifts from the teacher, namely getting good grades, getting prizes, getting congratulations, and thank you from the teacher." (RAI)

The teacher explained that the integration of religious values at MI Muhammadiyah Bloran was carried out since the beginning of students entering this school as students were taught to greet the teacher, greet the teacher using Arabic, then habituate the Duha prayer, listen to tausiyah delivered by the teacher, memorize letters, and congregational zuhr prayers. Meanwhile, based on the results of interviews with students, the reasons and goals they want to carry out religious values in daily life are (a) to be loved by Allah, (b) to create peace, order, and harmony in the school environment, (c) to gain knowledge, (d) to carry out Allah's commands, (e) carry out obligations, (f) be asked to learn, (g) because of Islamic religious guidance, and $(\mathrm{h})$ religious values lead us to goodness. As stated by SYA, BIL, ANN, 
"I want to carry out religious values because it is our obligation and to be loved by Allah SWT." (SYA)

"Because they were told to study and to gain knowledge." (BILL)

"Because religious values lead us to goodness and carry out God's commands." (ANN)

"Because Islamic religious guidance teaches that and to create peace, order, and harmony in the school environment." (RAI)

The success of the implementation of the integration program of religious values in the learning process at MI Muhammadiyah Bloran is measured through the implementation of performance evaluations. Performance evaluation is carried out four times a year, the way to measure the level of success of program implementation is to hold meetings with parents of students, open criticism and suggestions on social media, and observe student behavior in the teaching and learning process and activities at school. Based on the results of the current evaluation, the success rate of integrating religious values at MI Muhammadiyah Bloran is $70 \%-80 \%$, this number always experiences a significant increase every year, as evidenced by the increasing enthusiasm of parents to send their children to $\mathrm{MI}$ Muhammadiyah Bloran. Teachers and all staff of MI Muhammadiyah Bloran are still trying to maximize the implementation of integrating religious values in schools. As stated by $B S$, IA, IE, and IN:

"One year there are four evaluations." (BS \& IA)

"The way to measure the success of integrating religious values is to hold a meeting with the parents of the students, and we open criticism and suggestions both in writing and on social media. Alhamdulillah, the community's support for us is extraordinary." (IE)

"The way to measure the success of the integration of religious values is that the teacher observes every student's behavior in the teaching and learning process as well as the activities in the school." (HE)

"The success rate of integrating religious values, God willing, is 70-80\%." (IN)

"Alhamdulillah, every year the success rate of integrating religious values has always increased significantly, as evidenced by the increasing enthusiasm of parents in sending their children to our school. Religious values have not been fully implemented as expected. We still have a lot of homework to improve and we continue to innovate so that religious values can be optimally and optimally integrated in our school." (IE) 
Based on the statements, it can be concluded that the teacher follows up on students' social attitudes by informing them periodically. Then the students were never rewarded for the development of their social attitudes. The description of emergent themes is summarized in Table 2.

Table 2. Description of Emergent Themes

\begin{tabular}{|c|c|}
\hline Study Object & Findings \\
\hline $\begin{array}{l}\text { Religious values } \\
\text { in the learning } \\
\text { process. }\end{array}$ & $\begin{array}{l}\text { - } \quad \text { Clean creed: pray. } \\
\text { - } \quad \text { } \text { - } \text { Strongect worship: muroja'ah Al-Qur'an, Duha prayer, and Zuhur } \\
\text { others. } \\
\text { - } \quad \text { Strong body: snacks and lunch. } \\
\text { - } \quad \text { Broad insight: question and answer and draw conclusions. } \\
\text { - } \quad \text { Good at keeping time: BTA. } \\
\text { - } \quad \text { Organized his affairs: solving problems on time. } \\
\text { - Independent: trash alms. } \\
\text { - Helping others: peer teaching. }\end{array}$ \\
\hline $\begin{array}{l}\text { Strategy for } \\
\text { Integrating } \\
\text { Religious } \\
\text { Values }\end{array}$ & $\begin{array}{l}\text { - } \text { Assignment. } \\
\text { - } \text { Observing students in doing assignments. } \\
\text { - } \quad \text { Translating the vision and mission in the learning process } \\
\text { - Implementation of Islamic nuanced programs } \\
\text { - } \quad \text { Giving motivation } \\
\text { - } \quad \text { Siving advice } \\
\text { - } \quad \text { Gift-giving }\end{array}$ \\
\hline
\end{tabular}

\section{DISCUSSION}

Teachers act as role models and facilitators to instill religious values during the learning process. This is in line with the opinionIslamic (2016: 286) which states that the teacher is not only tasked with delivering subject matter, but also instilling positive character and morality.

The following are the religious values that are integrated by the teacher in the implementation of the learning process:

\section{Clean Faith}

Activities that are reflected in the integration of these values in the implementation of the learning process are prayer together at the beginning and end of each lesson. The virtue of praying is in the Qur'an, Allah commands us to pray so that we remember Him, this is also in accordance with the opinionHayati (2018: 69) that a Muslim should always remember Allah.

\section{True Worship}

Activities that are reflected in the integration of these values are muroja'ah Al-Qur'an in the preliminary activities, the Duha prayer before starting the lesson, and the Zuhur prayer 
during recess which is carried out in the congregation. This is relevant to the study of Harahap (2016: 96) There are two kinds of value integration, namely direct integration processes in the learning process such as reading the Qur'an before starting lessons and indirect processes such as midday prayers at school.

\section{Sturdy Morals}

Students are taught to have good morals by always being polite, polite, tolerant, mutual respect and respect for others in line with opinions Khulaisie (2016: 48) Politeness, courtesy, mutual respect, respect, tolerance, and greeting are steps for the formation of Muslim moral values in social relations.

\section{Strong Body}

Implementing a healthy lifestyle by consuming halal, clean, and nutritious food and drinks in line with opinions Hayati (2018: 115) that a Muslim must pay attention to physical health because preventing disease is more important than treatment.

\section{Extensive knowledge}

Familiarize students to think logically and critically in participating in learning activities in class according to their opinions Hayati (2018: 116) that there is no action that we must do, except that it must begin with thinking activity.

\section{Struggle Against Lust}

Students are taught to be able to control their passions and obey existing regulations. This is in accordance with finding of Hayati (2018: 117)that the passions that exist in every human being must be strived to submit to the teachings of Islam. The activity that illustrates the integration of this value is that students are biased to always be honest and not cheat while working on daily assessment evaluation questions, mid-semester assessments, and end-of-semester assessments. The cultivation of an honest attitude is in line with the opinion of Muttaqin (2018: 109) that honesty is the key to building student character and integrity.

\section{Smart Keeping Time}

Students take ten minutes at the end of the lesson to carry out BTA according to their opinion Hayati (2018: 117) that good use of time is an important factor for humans.

\section{Organized}

Students are taught to always be responsible, disciplined, careful, and thorough in carrying out their duties relevant to their opinions Hayati (2018: 119) that Muslims must be earnest, enthusiastic, and serious in carrying out their duties.

\section{independent}

Teaching students to give alms in harmony with opinions Hayati (2018: 119) which states that a Muslim must be able to allocate his wealth for alms, infaq, and zakat.

\section{Helpful for Others}

The activity that reflects the integration of this value is that students are accustomed to helping friends by applying peer teaching, where students who are able to teach friends who cannot. This is in accordance with the results of the studyHayati (2018: 120) that every Muslim must always think, prepare, and try his best so that he can be useful for others. 
Teacher's Strategy in Integrating Religious Values in the Learning Process

The strategy of integrating religious values in the learning process at MI Muhammadiyah Bloran is carried out by:

\section{Assignment}

Giving assignments to students aims to determine the level of students' understanding of the material and foster an attitude of responsibility. This is in line with the finding of Suyitno (2019:790) that the attitude of responsibility will be seen when students do the assignments given by the teacher.

\section{Observing Students in Doing Assignments}

In the implementation of the evaluation process, the teacher will carry out strict supervision. Such as when students work on daily assessment questions, mid-semester assessments, and end-of-semester assessments. Usually, the teacher will turn the table over during an exam, so that the drawer is facing forward and remind students to be honest and serious in doing their work. This is in accordance with the results of the studySuyitno (2019: 790) that the teacher observes students doing assignments with discipline aimed at instilling honesty and responsibility in students.

\section{Master's Example}

The teacher gives examples in the form of commendable actions and attitudes, besides that the teacher always invites and repeatedly reminds students to always apply religious values in everyday life. For example, the teacher always says good, neat, and friendly words. This is in line withMafrurah (2016: 94) that example is a way that has a big influence on the formation of students' character and personality.

Translating the Vision and Mission of School with Islamic Values Insight into the Learning Environment.

The vision and mission of MI Muhammadiyah Bloran is "Raising a Superior Generation of Islam". The school tries to achieve the vision and mission by including religious values in the lesson plans, implementing the integration of religious values in the learning process and evaluating learning. This is in line with the opinion Mafrurah (2016: 111) that religious values must be instilled in students to achieve the school's vision and mission.

\section{Implementation of Learning Programs with Islamic Values}

The Islamic nuanced learning program is carried out by the teacher by carrying out (1) greetings and prayers at the beginning and end of learning, (2) muroja'ah in preliminary activities, (3) school catering, (4) garbage alms, (5) BTA, (6) peer teaching. and (7) the congregational Duha, Zuhur, and Friday prayers.Firdaus (2016: 145) that Islamic programs are implemented in order to shape the habituation of Islamic values in students.

\section{Giving Motivation}

The teacher gives appreciation and motivation to students who have tried to behave well so that this behavior can be maintained. Examples are motivating by telling stories, stories of the prophet, stories of the prophet's companions, stories of personal experiences. They can take lessons from this story. In addition, usually after students pray the teacher says "Keep your prayer, because when you lose it you will lose the others." This is in accordance with study of Arfin (2017) that the provision of motivation can develop student activity, creativity, and initiative. 


\section{Giving Advice}

The teacher advises students who make mistakes and disobey rules such as chatting, joking, and falling asleep in class. The advice given is usually associated with religion. The purpose of giving advice is so that students will not repeat their mistakes in the future. This is in accordance with the results of the study Arfin (2017) that the advice given by the teacher will motivate students to always act and act according to the path of truth.

\section{Sanctions}

The teacher gives strict sanctions to students who do less commendable actions such as being crowded in class, smoking, truancy, being late, fighting, and not doing their homework. Sanctions are given according to the level of violation committed, gradually starting from light to severe sanctions according to the level of error and are educational in nature which aims to discipline and shape the character of students. Examples of sanctions given by teachers are memorizing short letters, writing surahs, writing statements signed by teachers and parents, cleaning the bathroom, istigfar a thousand times in front of the class, and collecting garbage. This is in accordance with the results of the study Arfin (2017) that sanctions to students must be in line with their mistakes. The goal is to discipline students and shape student character.

\section{Gift-giving}

Teachers give prizes to students who behave well and apply religious values. The purpose of giving gifts is to keep them motivated to continue to behave well in everyday life. Prizes are usually given to students who succeed in answering the teacher's questions, get good test scores, and succeed in getting class winners. Prizes are usually grades, money, stars, praise, and stationery such as pencils, pens, and erasers. This is in accordance with the opinionArfin $(2017: 106)$ that the prize aims to motivate students to be more active in participating in activities.

\section{CONCLUSION}

Based on the study results, it can be seen that (1) the integration of religious values in the learning process at MI Muhammadiyah Bloran is carried out through three stages, namely planning, implementation, and evaluation. There are ten religious values that are integrated in the implementation of the learning process. (2) Teachers use nine strategies to integrate religious values in the learning process. (3) Factors that support the integration of religious values in the learning process are teachers, parents, and the community in the school environment. While the inhibiting factors are the limited facilities and infrastructure, the diversity of student characteristics, the presence of provocateurs, and uncontrolled social interaction in the student's home environment.

The results of this study can be used as a reference on strategies and integration of religious values in the learning process for schools that will make school development programs regarding the integration of religious values in schools.

Religious values that are integrated into the learning process are by the 10 Muslim characteristics proposed by Hasan Al-Bana. Meanwhile, based on the self-determination theory proposed by Ryan \& Deci (2000), the results of integrating religious values in the learning process are still at the stage of external regulation.

\section{REFERENCES}

Arfin, M. (2017). Implementasi Nilai-nilai Pendidikan Karakter Pada SD Negeri Mannuruki Makassar [Implementation of Character Education Values at SD Negeri Mannuruki Makassar]. Universitas Islam Negeri Alauddin. 
http://repositori.uin-alauddin.ac.id/3425

Ariantini, N. P., Suandi, I. N., \& Sutama, I. M. (2014). Implementasi Pengintegrasian Sikap Spiritual dan Sosial dalam Pembelajaran Bahasa Indonesia Berbasis Kurikulum 2013 di Kelas VII SMP Negeri 1 Singaraja [Implementation of Integrating Spiritual and Social Attitudes in Indonesian Language Learning Based on the 2013 Curriculum in Class VII SMP Negeri 1 Singaraja]. EJournal Program Pascasarjana Universitas Pendidikan Ganesha, 3(1). https://ejournalpasca.undiksha.ac.id/index.php/jurnal_bahasa/article/view/1178/0

Aulia, L. R. (2014). Implementasi Nilai Religius dalam Pendidikan Karakter Bagi Peserta Didik di Sekolah Dasar Juara Yogyakarta [Implementation of Religious Values in Character Education for Students at the Yogyakarta Juara Elementary School]. V, 1-10.

Firdaus, I. H. (2016). Integrasi Nilai Islam dalam Pembelajaran Ilmu Pengetahuan Sosial di MI Miftahul Huda Turen Malang [Integration of Islamic Values in Social Science Learning at MI Miftahul Huda Turen Malang]. Universitas Islam Negeri Maulana Malik Ibrahim Malang. http://etheses.uin-malang.ac.id/9916/

Harahap, H. (2016). Pengintegrasian Nilai-nilai Agama Islam pada Pembelajaran di Sekolah Menengah Atas Negeri 1 Sihapas Kecamatan Sihapas Barumun Kabupaten Padang Lawas [Integrating Islamic Religious Values in Learning at State Senior High School 1 Sihapas, Sihapas Barumun District, Padang Lawas Regency]. Universitas Islam Negeri Sumatera Utara Medan. http://repository.uinsu.ac.id/1348/

Hayati, N. (2018). Hasan Al-Banna dan Konsep Kepribadian Muslimnya [Hasan Al-Banna and His Concept of Muslim Personality]. Universitas Islam Negeri Raden Intan Lampung. http://repository.radenintan.ac.id/6013/1/NURHAYATI\%20-\%201786108067.pdf

Islami, M. (2016). Character Values and Their Internalization in Teaching and Learning English at Schoolh. Dinamika IImu, 16(2), 279. https://doi.org/10.21093/di.v16i2.417

Khulaisie, R. N. (2016). Hakikat Kepribadian Muslim, Seri Pemahaman Jiwa Terhadap Konsep Insan Kamil [The Nature of Muslim Personality, A Series on Understanding the Soul of the Concept of Insan Kamil]. Jurnal Reflektika, 11(11), 39-57. http://dx.doi.org/10.28944/reflektika.v11i1.36

Kurniawan, M. I. (2013). Integrasi Pendidikan Karakter ke dalam Pembelajaran Kewarganegaraan di Sekolah Dasar [Integration of Character Education into Citizenship Learning in Elementary Schools.]. 37-45. https://doi.org/10.22219/jp2sd.v1i1.1528

Mafrurah, I. (2016). Internalisasi Nilai Religius pada Pembelajaran PAI dan Dampaknya Terhadap Sikap Sosial Siswa di Sekolah Menengah Atas [Internalization of Religious Values in PAI Learning and Its Impact on Students' Social Attitudes in High Schools]. Universitas Islam Negeri Maulana Malik Ibrahim Malang. http://etheses.uinmalang.ac.id/10313/1/14770065.pdf

Marini, A. (2018). Implementation of Character Building at Elementary Schools : Cases of Indonesia. $\quad 1(1), \quad 60-71 . \quad \mathrm{http}: / /$ seminars.unj.ac.id/icuic/wpcontent/uploads/2018/08/7.-Implementation-of-Character-Building-at-ElementarySchools-Cases-of-Indonesia-by-Arita-Marini-Universitas-Negeri-Jakarta.pdf

Miles, M. B.,\& Huberman, A. (2007). Analisis Data Kualitatif Buku Sumber Tentang MetodeMetode Baru. Terjemahan Tjejtep Rohendi Rohisis. Jakarta: Universitas Indonesia.

Moleong, L. J. (2013). Metodologi Penelitian Kualitatif [Qualitative Research Methodology]. Bandung: Remaja Rosda Karya.

Muttaqin, M. F. dkk. (2018). The Implementation Main Values of Character Education Reinforcement in Elementary School. Journal of Primary Education, 7(1), 103-112. https://journal.unnes.ac.id/sju/index.php/jpe/article/view/22766

Rudyanto, H. E., \& Retnoningtyas, W. A. (2018). Integrasi Nilai - nilai Karakter Melalui Pembelajaran Matematika di Sekolah Dasar [Integration of Character Values Through 
Mathematics Learning in Elementary Schools]. Prosiding Konferensi Ilmiah Dasar. 1(7), 34-43. http://prosiding.unipma.ac.id/index.php/KID/article/viewFile/446/425

Ryan, R. M., \& Deci, E. L. (2000). Self-Determination Theory and the Facilitation of Intrinsic Motivation, Social Development, and Well-Being. 55(1), 68-78. https://doi.org/10.1007/978-94-024-1042-6_4

Sugiyono. (2015). Memahami Penelitian Kualitatif [Understanding Qualitative Research]. Bandung: Alfabeta.

Suyitno, H. dkk. (2019). Integration of Character Valuesin Teaching-Learning Process of Mathematics at Elementary School of Japan. International Journal of Instruction, 12(3), 781-794. https://doi.org/10.29333/iji.2019.12347a

Wati, D. C., \& Arif, D. B. (2017). Penanaman Nilai-nilai Religius di Sekolah Dasar untuk Penguatan Jiwa Profetik Siswa [Instilling Religious Values in Elementary Schools for Strengthening Students' Prophetic Spirit]. Konferensi Nasional Kewarganegaraan III, (November), 60-63. http://eprints.uad.ac.id/9629/

Yusuf, A. A. (2003). Studi Agama Islam [Islamic Religious Studies]. Bandung: CV Pustaka Setia. 